Original Paper http://ajol.info/index.php/ijbcs http://indexmedicus.afro.who.int

\title{
Impact of chlorination on the microbiological quality of drinking water in school area: case study of Central North Region in Burkina Faso
}

\author{
Aminata KABORÉ ${ }^{1 *}$, Boubacar SAVADOGO ${ }^{2}$, Almamy KONATÉ ${ }^{1}$, \\ Jacques SAWADOGO ${ }^{1}$, W. Paul SAVADOGO ${ }^{1}$, I. Brigitte KABORÉ ${ }^{3}$,
} Z. P. Lambert NIKIÉMA ${ }^{3}$ and Dayéri DIANOU ${ }^{2}$

\author{
${ }^{1}$ Institute of the Environment and Agricultural Research (INERA), 04 BP 8645 Ouagadougou, Burkina Faso. \\ ${ }^{2}$ Institute of Research in Health Sciences (IRSS), 03 BP 7192 Ouagadougou, Burkina Faso. \\ ${ }^{3}$ Catholic Relief Services (CRS), 01 BP 469 Ouagadougou 01, Burkina Faso. \\ *Correspondence author; S/C INERA 04 BP 8645 Ouagadougou 04, Burkina Faso; \\ Tel: + 226703856 99/789593 89; E-mail: kab.amina@yahoo.fr
}

\begin{abstract}
In Burkina Faso, despite the realization of drilling, the consumption of safe drinking water remains a major concern in rural school area. To guarantee the consumption of safe drinking water, the project namely "koom-yilma" was opted for the chlorination of water with "Mini-WATA" in rural school area in CentralNorth region in Burkina Faso. This study aimed to evaluate the impact of this program in nine schools few months after its implementation. Thus, different water samples were analyzed following the membrane filtration method with specific culture media to identify and count fecal coliforms, E. coli and fecal streptococci. The results compared with those obtained before the program showed the efficiency of the intervention. Indeed, $40.45 \%$ of water samples from students was safe versus $5.05 \%$ before the intervention according to the WHO standard. For the $59.55 \%$ contaminated water, the number of fecal bacteria was low compared with untreated water. Despite this good results, the percentage of contaminated water still high in some schools because of lack of hygiene. Thus, the improvement of hygiene practices is necessary to ensure the microbiological quality of drinking water in addition to chlorination.
\end{abstract}

(C) 2018 International Formulae Group. All rights reserved.

Keywords: Drinking water, Mini-WATA, chlorine, disinfection, hygiene, school area.

\section{INTRODUCTION}

The lack of access to clean water, improved sanitation and adequate hygiene (WASH) are major contributors to the burden of several infectious diseases (Strunz et al., 2014; Stocks et al., 2014). These diseases, as they primarily persist in socially and economically deprived communities especially in rural area (Hotez et al., 2009; Utzinger et al., 2009). According to data from the 2013 of Global Burden of Disease Study (GBD) and the World Health Organization/United Nations Children's Fund "joint monitoring program for water supply and sanitation", $7 \%$ of deaths in children aged 8-14 years in Burkina Faso was caused by diarrheal diseases, with over $96 \%$ attributed to inadequate WASH conditions as primary risk factor (WHO and UNICEF, 2012; Institute for Health Metrics and Evaluation, 2013). The 
pathogenic agents associated with lack of WASH cause substantial gastrointestinal morbidity, malnutrition and mortality (Stanley, 2003; Feng et al., 2011).

In Burkina Faso, the drinking water supply policy is essentially based on the realization of drillings in rural area without taking into account the quality of water consumed by populations (PN-AEPA, 2006). Indeed, in this area, the populations are confronted with optimal management of water supply points and traditional water sources attendance (Aouba, 2012). That's a one of causes of contaminated water consumption. Several studies showed a significant microbiological pollution of water in both domestics and schools areas (Dianou et al., (2002; 2004); Mbawala et al., 2010; Nkurunziza, 2013; Souncy et al., 2015; Gnazou et al., 2015; Tamungang et al., 2016; Sokegbe et al., 2017; Kaboré et al., 2017). That's essentially related to bad hygiene practices, the lack of sanitation and appropriate disinfection methods in house and school levels. In school area, the assessment of water quality stored in classrooms and those from children's drinking water cups revealed a high contamination with fecal coliforms, E. coli and fecal streptococci (Erismann et al., 2016a; 2016b; Kaboré et al., 2017). In view of this situation, the project namely "koom yilma" was opted for the disinfection of drinking water with sodium hypochlorite (bleach) in rural schools located in Central-North region in Burkina Faso. This method recognized by the WHO is sure, effective and cheapest for water purification (WHO, 2006). Moreover, the persistent action of sodium hypochlorite preserves the quality of water against microbial contamination.

This study aimed at evaluating the effectiveness of this program to improve the quality of drinking water in school area in order to consider a large scale implementation in Burkina Faso.

\section{MATERIALS AND METHODS \\ Study area}

The North-Central region is located in the central zone of Burkina Faso between parallels $122^{\circ} 40^{\prime} 1 ; 14^{\circ}$ North $(\mathrm{N})$ and meridians $0^{\circ} 15 ; 25^{\circ}$ West longitude (W). It occupies $18.212 \mathrm{~km}^{2}$ and it's subdivided into three (3) provinces namely Bam, Namentenga and Sanmatenga (Regional Council of North Central, 2014). In this region, $42 \%$ of schools don't have drillings and education rate is low (71.3\%) compared to national rate $(80.3 \%)$ (MAH, 2012).

This program concerned 10 of 107 schools which participate at the first step of project "koom-yilma". Among the ten (10) primary schools selected, nine (9) schools have actually participated in this program (Kaboré et al., 2017). These are the primary schools of Kinkirgo, Ouedsé, Loagha Catholic, Loada, Gabou, Sirgui, Mane Mossi, Zana, and Barkana. Figure 1 shows the location of these schools in North Central. Figure 1 presents the localization of these schools in Central North region in Burkina Faso.

\section{Presentation of "Mini-WATA"}

To implement the program, "koom yilam" provided all the schools with "MiniWATA" to produce chlorine and treat drinking water. "Mini-WATA" is a simple device which produce a sodium hypochlorite from salt water. With $25 \mathrm{~g} / \mathrm{L}$ of salt water it produce $6 \mathrm{~g} / \mathrm{L}$ of active chlorine (Antenna Technology, 2017). This chlorine can disinfect 4,000 liters of water, ensuring the daily consumption of approximately 1,000 people.

Production and treatment of water with sodium hypochlorite produced with "MiniWATA" in school area

In the schools, teachers and parents were trained to produce sodium hypochlorite and treat water according to "Mini-WATA" manual instructions (Antenna Technology, 2017). The project recommended to treat water from drillings each morning and store treated water in appropriate reservoirs in classrooms for students' consumption.

\section{Water sampling and analysis}

Few months after the implementation of the program, the microbiological quality of drinking water was assessed in these schools. 
Water sampling consisted in taking of $100 \mathrm{ml}$ of water from the storage containers in the classrooms and from children's drinking water cups, with sterile glass bottles. Water samples were stored at $4{ }^{\circ} \mathrm{C}$ in a cool box and carried to the laboratory for microbiological analysis according to French standard EN ISO 19458 (2006).

Three (3) bacterial indicators of fecal pollution namely Escherichia coli, fecal coliforms, fecal streptococcus were isolated and counted by the membrane filtration technique according to the European standard NF IN ISO 9308-1 (2000). Bacterial cells were concentrated on a $0.2 \mu \mathrm{m}$ millipore membrane filter followed by culture on the chromogenic RapidE. coli 2 agar (BIO RAD) medium which contains 2 substrates specific to the $\beta$-D-Glucuronidase (Gluc) and $\beta$-D-
Galactosidase (Gal) enzymes, respectively. Incubation was performed at $44.5^{\circ} \mathrm{C}$ for $24 \mathrm{~h}$. Colonies of E. coli (Gal+/Gluc+) appear at purple to pink while other coliforms colonies stain at blue. On the Bile Esculine Azide medium, Gram positive cells able to reduce Esculine as fecal streptococci stained black after $24 \mathrm{~h}$ incubation period at $37^{\circ} \mathrm{C}$, while Gram negative and other Gram positive cells are inhibited by sodium Azide.

\section{Statistical analysis}

Data were analyzed with statistical software R. The analysis of variance (ANOVA) permitted to compare mean bacteria concentrations with those obtained before the implementation of the program in schools.

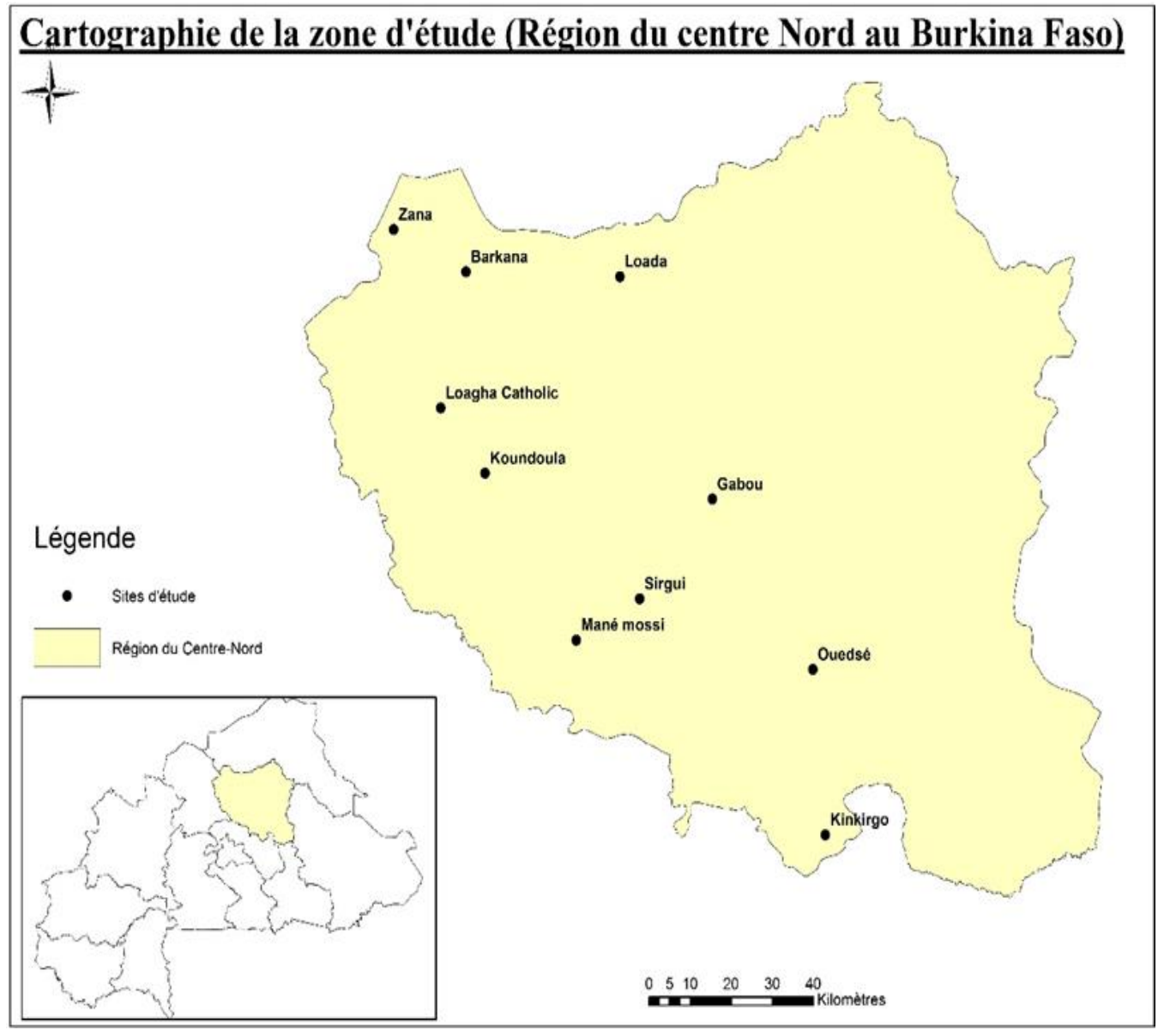

Figure 1: Location of the nine (9) study schools. 


\section{RESULTS}

\section{Effect of treatment on the microbiological quality of water stored in the classrooms}

For water samples stored in classrooms, the treatment with sodium hypochlorite showed a significant decrease of fecal coliforms $\left(\mathrm{p}<2.29 \mathrm{e}^{-05}\right), E$ coli $\left(\mathrm{p}<3.659 \mathrm{e}^{-}\right.$ $\left.{ }^{06}\right)$ and fecal streptococci $(\mathrm{p}<0.0001541)$ in all the schools. Figures $2 \mathrm{a}, 2 \mathrm{~b}, 2 \mathrm{c}$ present respectively the effect of treatment (T1) on fecal coliforms, E coli and fecal streptococci. It appears a significantly decrease of fecal bacteria in drinking water in all the schools except those of Sirgui, Gabou, Loagha Catholic and Mané Mossi (Figures 2a, 2c). Indeed, during the intervention, $25 \%, 100 \%$, $100 \%, 80 \%, 66.66 \%, 30 \%$ of water stored in classrooms respectively from Kinkirgo, Ouedsé, Loada, Barkana and Zana were safe versus $0 \%, 33.33 \%, 66.66 \%, 30 \%, 0 \%$ without any treatment. That shows an improvement of water quality stored in classrooms in these schools. However, for water samples from Sirgui, Gabou, Mané Mossi and Loagha Catholic, the proportion of contaminated water increased of $67 \%, 60 \%$ and $33.33 \%$ respectively during the intervention. In these schools, the chlorination wasn't applied regularly according the recommendation.

\section{Effect of treatment on the microbiological quality of water from children's cups}

Concerning water samples from children's drinking cups, the results showed a significant decrease of fecal coliforms $\left(\mathrm{p}<8.65 \mathrm{e}^{-07}\right), E$ coli $(\mathrm{p}<0.0002484)$ and fecal streptococci $(p<0.007820)$. The effect of treatment (T1) is presented in figures $3 \mathrm{a}, 3 \mathrm{~b}$ and $3 \mathrm{c}$ respectively for fecal coliforms, $E$. $c o l i$, fecal streptococci. For all water samples, the results showed a significant decrease of fecal bacteria in water samples from children's drinking water cups except those from Mané Mossi (Figures 3a, 3b and 3c). Indeed, according to the schools, the percentage of safe water during the program was $18 \%, 16 \%, 25 \%, 70 \%, 27.27 \%, 27 \%$, $55.55 \%, 66.6 \%$ respectively for Loagha Catholic, Sirgui, Gabou, Kinkirgho, Ouedsé, Loada, Barkana, Zana versus $0 \%$ without any treatment for all these schools except Loagha Catholic (18\%). For water samples from Mané Mossi, the percentage of contamination remained unchanged. Globally, the treatment improved the quality of children's drinking water.

However, despite the significant reduction of fecal bacteria, the proportion of water contaminated is still high because of lack of water equipment maintenance, bad hygiene practices and the irregularity of treatment.

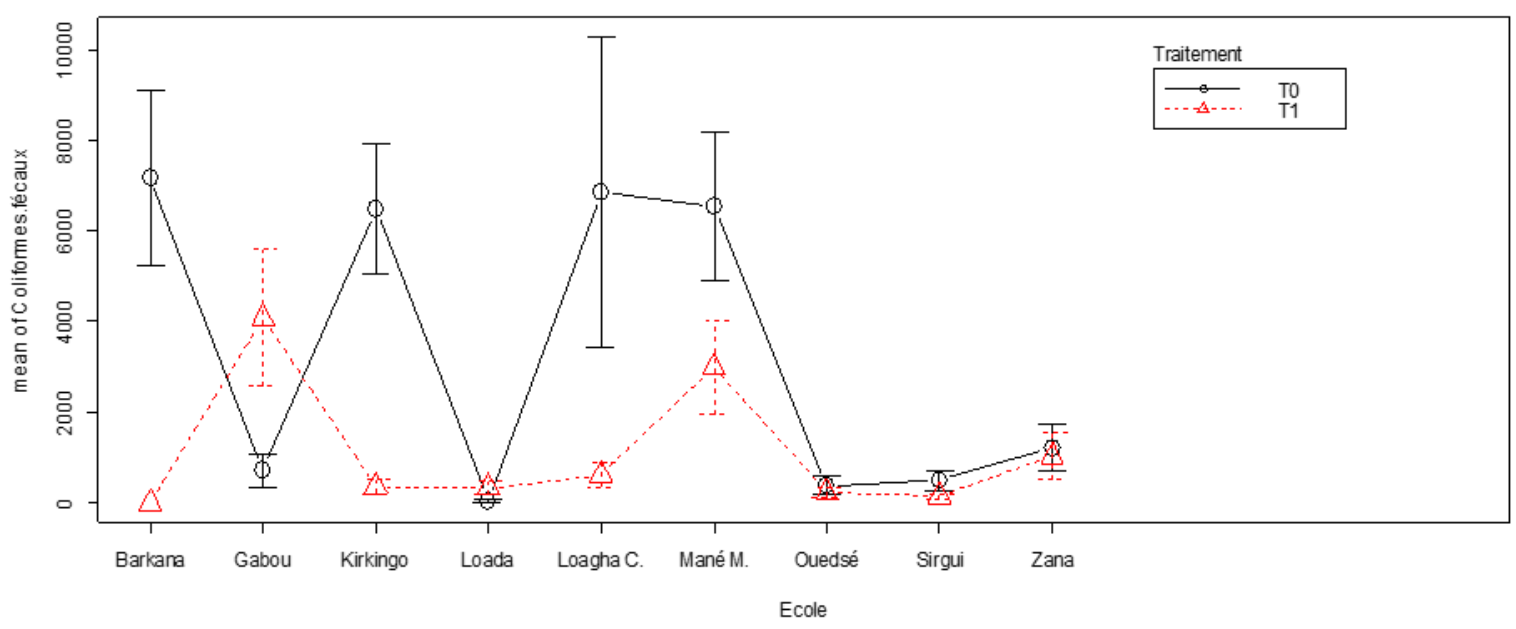

Figure 2a: Effect of chlorination (T1) on fecal coliforms in water samples stored in classrooms. 


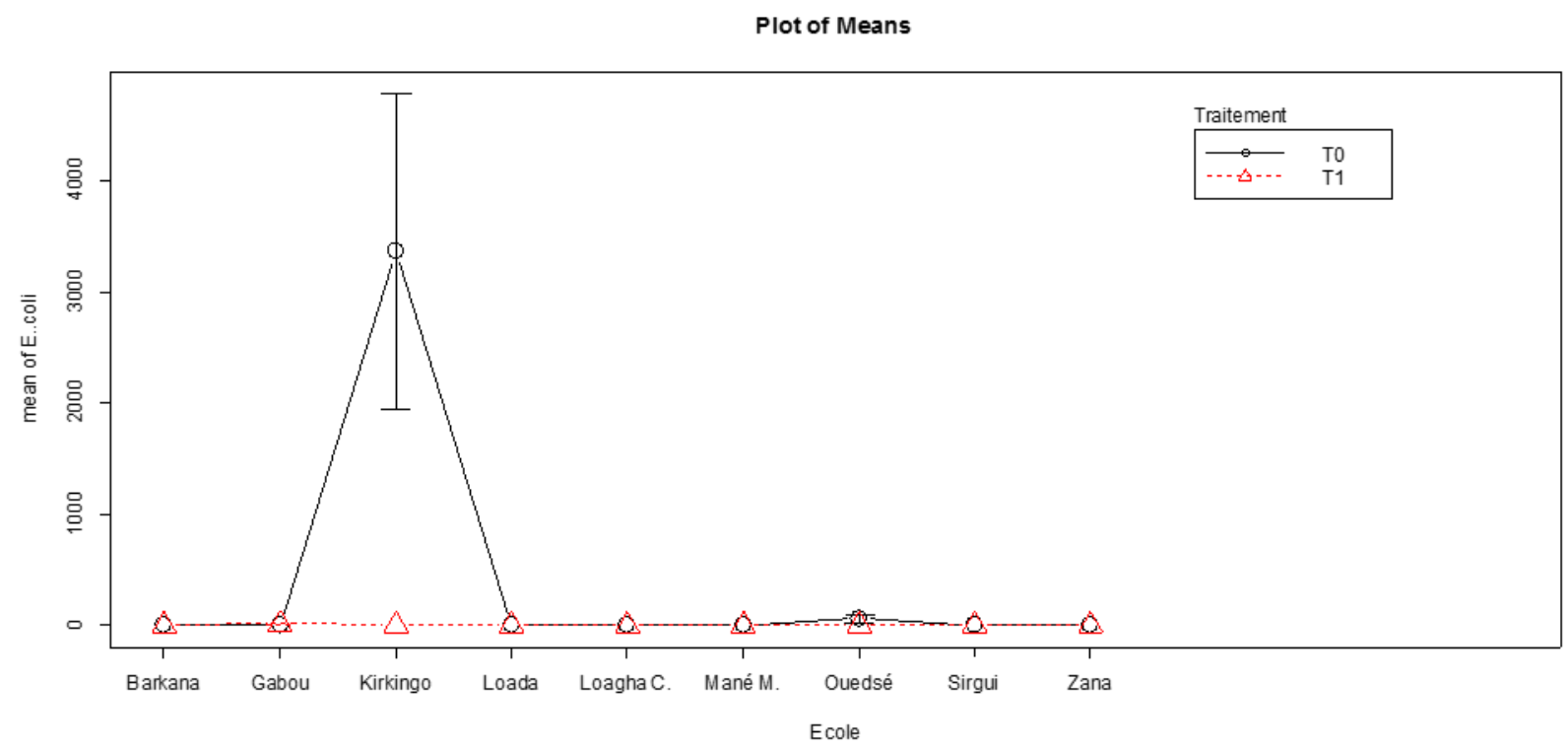

Figure 2b: Effect of chlorination (T1) on E. coli in water samples stored in classrooms.

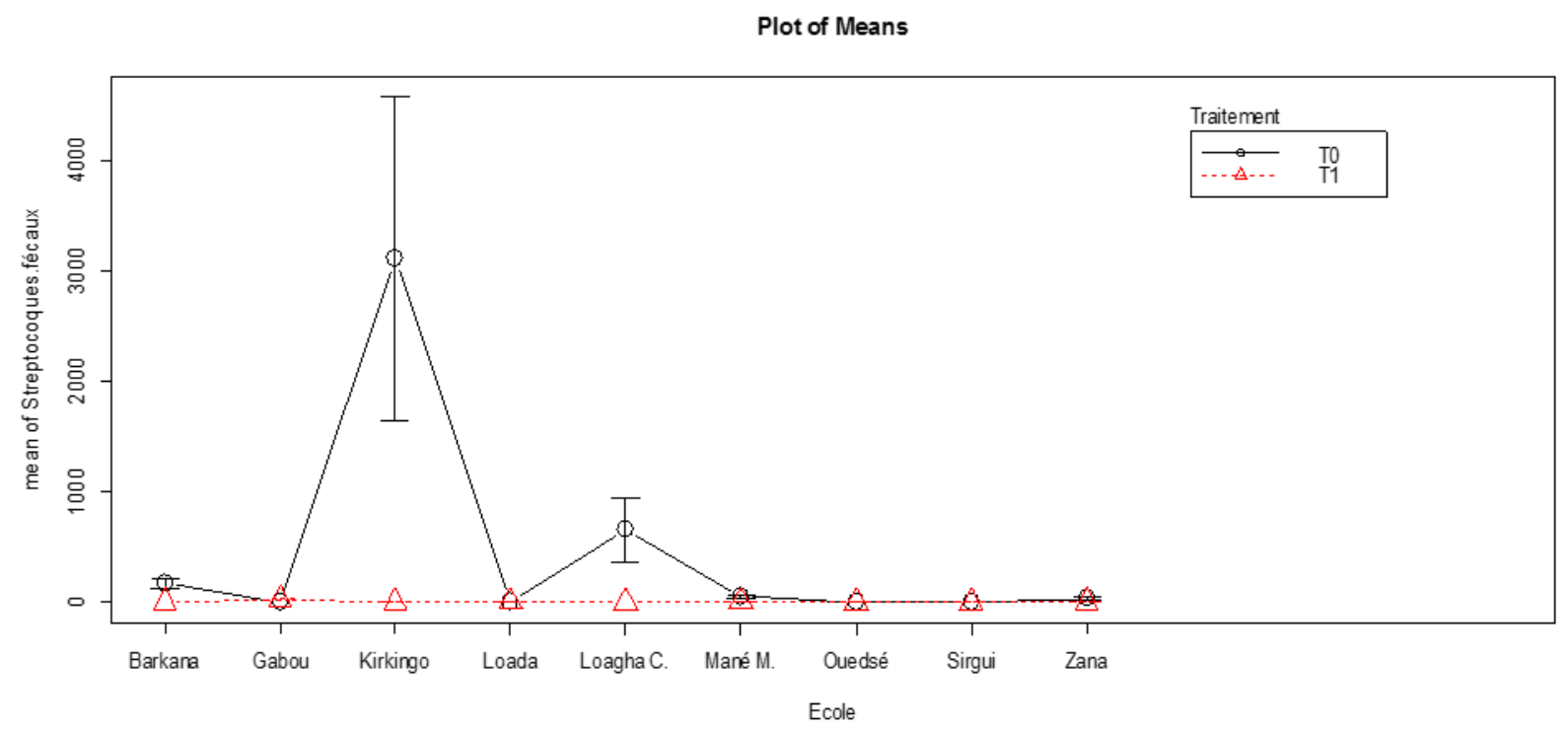

Figure 2c: Effect of chlorination (T1) on fecal streptococci in water samples stored in classrooms. 


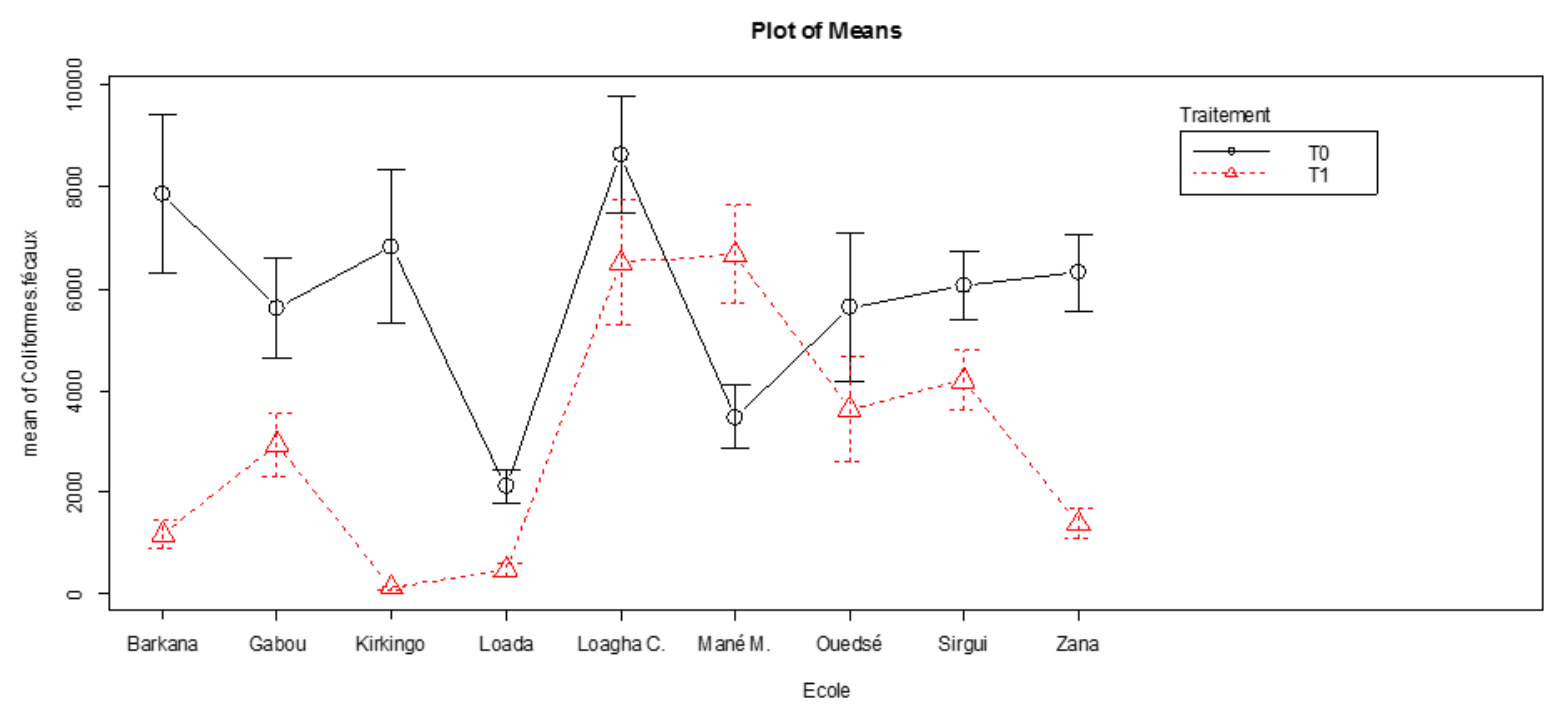

Figure 3a: Effect of chlorination (T1) on fecal coliforms in water samples from children's drinking water cups.

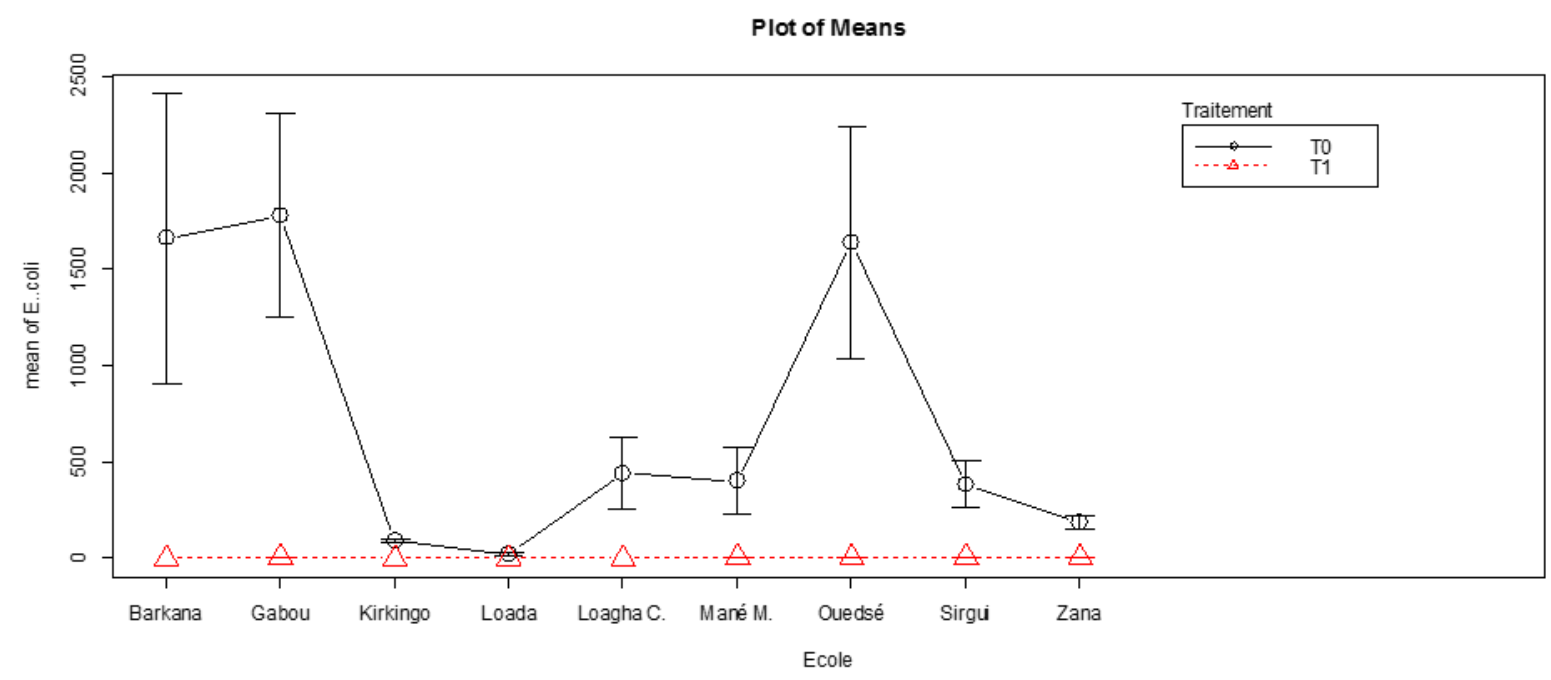

Figure 3b: Effect of chlorination (T1) on E. coli in water samples from children's drinking water cups. 


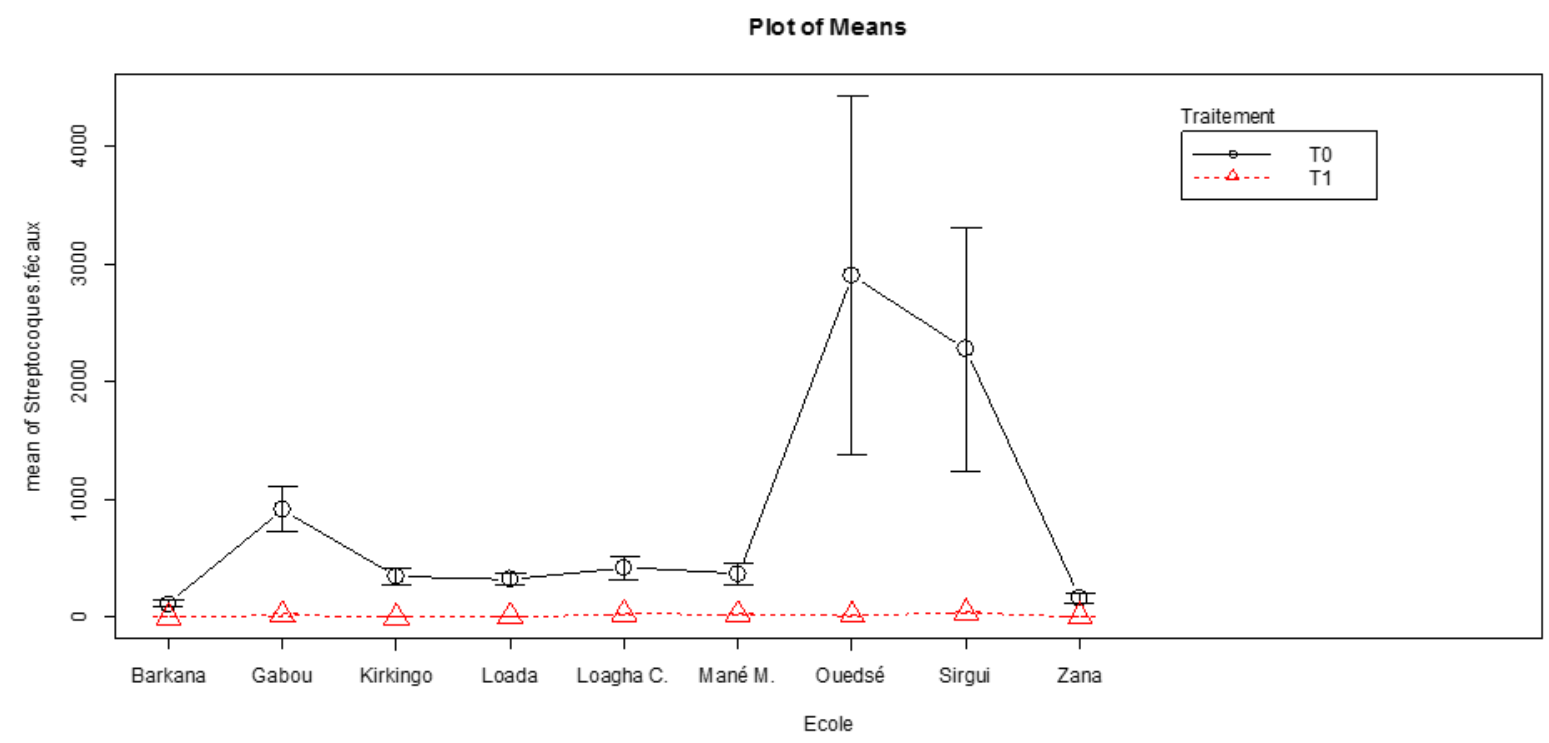

Figure 3c: Effect of chlorination (T1) on fecal streptococci in water samples from children's drinking water cups.

\section{DISCUSSION}

With all the schools combined, the results showed that $40.45 \%$ of students drank safe water during the program versus $5.05 \%$ before the intervention according to WHO standards. In addition, the number of bacteria in water contaminated were low compared to untreated water. This result shows the efficiency of treatment in rural schools. However, during water sampling, we observed a little involvement of teachers at the program. In Gabou, Mané Mossi and Loada, drinking water was not regularly treated according to the program recommendation. This situation explains the increase of fecal bacteria in water stored in some classrooms (Figures 2, 3, 4). Moreover, in the other classrooms, the treatment wasn't repeated when treated water finished before the end of courses. In these cases, the storage reservoirs still empty or filled by children with unappropriated hygiene practices. In addition, water storage reservoirs and cups were not regularly washed. All these factors contribute to explain the contamination of water stored in classrooms.

Concerning water samples from children's drinking cups, the results showed a decrease of all fecal bacteria (Figures 3a, 3b, 3c) during the program. But, many children still bring untreated water from their houses or other sources. Therefore they didn't consummate treated water from schools. Additional, student's cups used to consummate water are not washed regularly. That's explains the high number of fecal bacteria in their drinking water.

In view of these findings, it is necessary to revise the process in schools. Indeed, for treated water storage in classrooms, it will be more judicious to use big capacity containers to provide safe water away. Teachers must regularly treat water and make sure the container is washed before putting drinking water. The students must be train to produce and treat water and hygiene practices must be improve in schools. Thus, according to UNICEF, interventions including education on hygiene and hands washing can reduce by $45 \%$ the number of diarrheal diseases cases (UNICEF, 2006). Thereby, it will be important to implement school health clubs to sensitize and train children and make sure that hygiene practices are good in the schools (Erismann et al., 2016b).

\section{Conclusion}


The chlorination improve drinking water quality and reduce the risks of waterborne diseases such as cholera, typhoid fever and gastro-enteritis in schools. The disinfection of water with Mini-WATA is a good approach to ensure safe drinking water in rural school area in Burkina Faso. Its easy use and the low cost of production of hypochlorite sodium make this technology suitable for rural area. However, its implementation requires a rigorous training and the involvement of teachers and students.

\section{COMPETING INTERESTS}

The authors declare that they have no competing interests.

\section{AUTHORS' CONTRIBUTIONS}

$\mathrm{AK}$ and $\mathrm{BS}$ designed the research proposal, analyzed the water samples and wrote the manuscript. WPS, JS and AKO performed the statistical analysis and contributed to write the manuscript. IBK, ZPLN implemented activities in schools. DD supervised the study.

\section{ACKNOWLEDGEMENTS}

The authors would like to express profound gratitude to Catholic Relief Services for financial and technical supports and the implementation of this program. We also thank teachers for their participation and their availability for this study.

\section{REFERENCES}

Antenna Technology. 2017. Mini-WATA manual, Antenna Foundation, Geneva, p.16.

Aouba S. 2012. Empirical Indicators of Sustainable Human Development: The Case of Access to Drinking Water in the Rural Town of Saaba Burkina Faso. Master Thesis, USTA, Ouagadougou, p. 50.

Council of North-Central Regional. 2014. Development Plan of North-Central Regional 2015-2019. Ouagadougou, 202 p.

Dianou D, Poda JN, Sorgho H, Thiombiano L. 2002. Quality of Households Drinking Water at Thion, Blédougou and Kangoura in Burkina Faso. South
Sciences and Technologies, 9(1): 25-33. ISSN 0796-5419.

Dianou D, Poda JN, Thiombiano L, Sorgho H. 2004. Evaluation of Contamination Tracks and Some Disinfecting Methods of Households' Drinking Water in Rural Area: Case Study of Thion village in Burkina Faso, University of Ouagadougou Press: Ouagadougou; 168181.

Erismann S, Diagbouga S, Odermatt $\mathrm{P}$, Knoblauch AM, Gerold J, Shrestha A, Tarnagda G, Kaboré A, Schindler C, Utzinger J, Cissé G. 2016. Prevalence of intestinal parasitic infections and associated risk factors among schoolchildren in the Plateau Central and Centre-west regions of Burkina Faso. Parasites \& Vectors., 9(554): 1-14. DOI: 10.1186/s13071-016-1835-4,

Erismann S, Shrestha A, Diagbouga S, Knoblauch AM, Gerold J, Herz R, Sharma S, Schindler C, Odermatt P, Drescher A, Yang R, Utzinger J, Cissé G. 2016. Complementary school garden, nutrition, water, sanitation and hygiene interventions to improve children's nutrition and health status in Burkina Faso and Nepal: a study protocol. BMC Public Health., 16(244): 1-11. DOI 10.1186/s12889-016-2910-7

Feng Y, Xiao L. 2011. Zoonotic potential and molecular epidemiology of Giardia species and giardiasis. Clin. Microbiol. Rev., $\quad \mathbf{2 4}(1): 110-140 . \quad$ DOI: 10.1128/CMR.00033-10.

French standard. 2006. Sampling for Microbiological Analysis of water (1 edn). International Organization for Standardization, Geneva.

French standard. 2000. Detection and enumeration of Escherichia coli and coliform bacteria, (part1). International Organization for Standardization, Geneva.

Gnazou MDT, Assogba K, Sabi BE, Bawa LM. 2015. Physicochemical and bacteriological quality of water used in schools of the prefecture of Zio (Togo). Int. J. Biol. Chem. Sci., 9(1): 504-516. DOI: http://dx.doi.org/10.4314/ijbcs.v9i1.43 
Hotez PJ, Fenwick A, Savioli L, Molyneux DH. 2009. Rescuing the bottom billion through control of neglected tropical diseases. Lancet, 373(9674):1570-1575. DOI: 10.1016/S0140-6736(09)60233-6.

Institute for Health Metrics and Evaluation. 2013. Global Burden of Disease compare and visualization. University of Washington Press: Washington.

Kaboré A, Savadogo B, Savadogo J, Konaté A, Savadogo WP, Kaboré IB, Nikiéma ZPL, Dianou D. 2017. Problematic of microbiological quality of drinking water in rural schools area: Case of NorthCentral Region in Burkina Faso. CAMES Rev., 5(2).

Mbawala A, Abdou, Ngassoum MB. 2010. Evaluation of physicochemical and microbiological pollution of dam's water in Dang-Ngaoundéré (Cameroon). Int. J. Biol. Chem. Sci., 4(6): 1962-1975. http://ajol.info/index.php/ijbcs.

Ministry of Agriculture. 2006. Report of National Program of Drinking Water and Sanitation Supply for 2015 Year Issue. Direction of Hydraulics Resources Inventory, Hydraulics and Fishing Resources, Ouagadougou.

Ministry of Agriculture and Hydraulics. 2012. Statistical Yearbook 2011 for Drinking Water and Wastewater and Excreta Sanitation. Ouagadougou, 258 p.

Nkurunziza G. 2013. Study of the quality of drinking water along the water chain in households in three regions of Burkina Faso: case of the villages of Kamboinsé, Koubri, Sikoro and Bapla. Master's thesis, International Institute of Water and Environment, Ouagadougou, p. 84.

Sokegbe OY, Djeri B, Kogno E, Kangnidossou M, Mensah RT, Soncy K, Ameyapoh Y. 2017. Health risks related to sources of drinking water in district $\mathrm{n}^{\circ} 2$ of Lomé commune: case of Adakpamé neighborhood. Int. J. Biol. Chem. Sci., 11(5): 2341-2351. DOI: https://dx.doi.org/10.4314/ijbcs.v11i5.31

Soncy K, Djeri B, Anani K, Eklou-Lawson M, Adjrah Y, Karou DS, Ameyapoh Y, De Souza C. 2015. Assessment of bacteriological quality of drinking water in wells and drilling in Lomé, Togo. $J$. Appl. Biosci., 9(1): 8464 - 8469. DOI: http://dx.doi.org/10.4314/jab.v91i1.6

Stocks ME, Ogden S, Haddad D, Addiss DG, McGuire C, Freeman MC. 2014. Effect of water, sanitation, and hygiene on the prevention of trachoma: a systematic review and meta-analysis. PLoS Med., 11(2): $1-29 . \quad$ DOI: 10.1371/journal.pmed.1001605

Strunz EC, Addiss DG, Stocks ME, Ogden S, Utzinger J, Freeman MC. 2014. Water, sanitation, hygiene, and soil-transmitted helminthic infection: a systematic review and meta-analysis. PLoS Med., 11(3): 138.

DOI:

10.1371/journal.pmed.1001620.

Stanley SL. 2003. Amoebiasis. Lancet, 361(9362): 1025-1034. DOI: 10.1016/S01406736 (03)12830-9

Tamungang NEB, Biosengazeh NF, Alakeh MN, Tameu DY. 2016. Quality control of domestic water in Babessi village in North West in Cameroon. Int. J. Biol. Chem. Sci., 10(3): 1382-1402.DOI: http://dx.doi.org/10.4314/ijbcs.v10i3.37

UNICEF. 2006. Progress for Children: A report card on water and sanitation (5th edn). UNICEF, New York.

Utzinger J, Becker SL, Knop S, Blum J, Neumayr AL, Keiser J. 2012. Neglected tropical diseases: diagnosis, clinical management, treatment and control. Swiss Med Wkly., 22(142): 1-24. DOI: 10.4414/smw.2012.13727.

WHO (World Health Organization) and UNICEF (the United Nations Children's Fund). 2012. Progress on Drinking Water, Sanitation and Hygiene: 2012 Update and SDG Baselines. Anna Grojec: Geneva.

World Health Organization. 2011. Guidelines for Drinking Water Quality, (4th Edn), WHO Press, Geneva.

World Health Organization. 2004. Water treatment and pathogen control, IWA publishing Geneva. 